Technical Article

\title{
QR Code technology in a sensory garden as a study tool
}

\author{
Rafaela de Fatima Rocha Prestes ${ }^{1}$, Pedro Henrique Furquim Cordeiro ${ }^{1}$, Fernando Periotto ${ }^{1}$, Daniel Baron ${ }^{1 *}$
}

\begin{abstract}
Sensory Gardens are considered non-formal learning environments, however, they are not used as a methodological alternative for teaching in Brazil. The installation of the QR Code in a Sensory Garden is innovative and the link to in a non-formal learning environment can attract and retain student's attention. Our study tested the hypothesis that Public School students between the ages of 13 and 15 years old are not stimulated by subjects taught in the area of botany when exposed to non-formal learning environments. The study selected 23 students, divided into two teams, in which one obtained access to the Sensory Garden and the other team was restricted to the content addressed in the formal learning environment. 'Diagnostic questionnaires' were applied to assess botanical knowledge, before and after the activity, comparing results between teams. From the data obtained, it was possible to prove the effectiveness of the Sensory Garden in the student's botanical learning process. Our results indicate that the use of QR Code technology contributed to students' improvement and interest in botany, while arousing curiosity and enthusiasm to observe, in loco, the content previously covered in the classroom. In assessing botanical knowledge among participants, this study reported that students attending the Sensory Garden showed better performance compared to students who did not attend the Sensory Garden. Therefore, we reject the hypothesis tested and accept that the Sensory Garden using QR Code was relevant and contributed as a study tool for 13 to 15 years old students from Public High-schools.
\end{abstract}

Keywords: Botany, non-formal learning environment, public high-school, quick-response-code.

\section{RESUMO}

Tecnologia $Q R$ code em jardim sensorial como ferramenta de estudo

Jardins Sensoriais são considerados ambientes não formais de ensino, porém não são utilizados como alternativa metodológica de ensino no Brasil. A instalação de $Q R$ Code em um Jardim Sensorial é inovador e, atrelá-lo em ambiente não formal de ensino, pode atrair a atenção dos estudantes. Este estudo testou a hipótese de que estudantes, entre 13 e 15 anos, da Escola Pública, em contato com ambientes não formais de aprendizagem, não são estimulados por disciplinas ministradas na área de botânica. Vinte e três estudantes foram selecionados para o estudo e divididos em duas equipes, em que uma obteve acesso ao Jardim Sensorial e a outra equipe ficou restrita ao conteúdo abordado no Ambiente Formal de Ensino. Foram aplicados 'questionáriosdiagnósticos' para avaliar o conhecimento botânico, antes e após a atividade, comparando os resultados entre as equipes. A partir dos dados obtidos foi possível comprovar a eficácia do Jardim Sensorial no processo de aprendizagem botânica dos estudantes. Nossos resultados apontam que a utilização da tecnologia $Q R$ Code contribuiu para o aprimoramento e interesse dos estudantes por botânica, além de aguçar a curiosidade e entusiasmo ao observar, in loco, o conteúdo previamente abordado em sala de aula. Ao avaliarmos o conhecimento botânico entre os participantes reportamos que estudantes que frequentaram previamente o Jardim Sensorial, mostraram melhor desempenho em relação aos estudantes que não frequentaram. Portanto, rejeitamos a hipótese testada e aceitamos que o Jardim Sensorial, com o uso da ferramenta $Q R$ Code, mostrou-se relevante e contribuiu como ferramenta de estudo para jovens estudantes da Rede Pública de Ensino entre 13 a 15 anos de idade.

Palavras-chave: Ambiente-não-formal-de-ensino, botânica, quick-response-code, rede pública de ensino.

\section{Introduction}

Currently, there is high difficulty in addressing didactic content on botany in 'formal learning environments'. The distance between 'Man and Nature' contributes to the lack of interest in the subject, besides the fact that the contents about Botany, addressed in class, most of the time are done through handouts and content memorization, becoming uninteresting to young students (Souza and Garcia, 2019). The use of non-formal learning environments promotes knowledge dynamically and helps in understanding the contents covered in formal learning environments. This

${ }^{1}$ Federal University of São Carlos, Natural Sciences Center, Buri-SP, Brazil. *Corresponding author: danielbaron@ufscar.br

Received Nov 18, 2019 | Accepted Apr 21, 2020| Available online May 11, 2020

Licensed by CC BY 4.0

https://doi.org/10.1590/2447-536X.v26i2.2114

Area Editor: Marcelo Vieira Ferraz 
strategy allows learning of various subjects in places such as zoos, museums, gardens and other spaces with activities directed to content (Cascais and Terán, 2014).

The use of gardens as a tool for study and pedagogical/ social integration has spread throughout Europe, Asia, and America, however, there are still few accessible public gardens for teaching purposes in the world (Leão, 2008). Sensory gardens are leisure spaces designed to stimulate and sharpen the five senses of the human body: touch, smell, taste, sight, and hearing, besides promoting environmental awareness and proposing a pleasant methodology in teaching about plant species (Santos and Dionísio, 2016). Some Higher Education Institutions open the space for gardens to promote education and culture, allowing the deployment and use of appropriate technologies for knowledge dissemination.

Currently, national education is undergoing transformations due to the popularization of technological advances, for example, internet access. In view of this, it is essential to reflect on new methodological strategies that meet current demands and improve teaching and learning today (Fabeni, 2015). Among the possible technologies that narrow the teaching-learning relationship, the QR Code is a virtual tool and can be used as a strategy to attract the attention of young people. (Nichele et al., 2015).

The present study analyzed the possible learning connections of Public High-school students from the public school system using botanical contents, specifically the organization of medicinal, ornamental species and Unconventional Food Plants (UFD), conducted in a nonformal learning environment, from the establishment of a Sensory Garden. Our study tested the hypothesis that students, between 13 and 15 years, from Public School, in contact with non-formal learning environments, are not stimulated by subjects taught in the area of botany.

\section{Material and Methods}

Before starting the research, the study was evaluated and approved by the Human Research Ethics Committee (Process Number: 3.322.778), which defends the integrity and dignity of research participants, so that they can find themselves within ethical standards.

\section{Sensory Garden Installation}

The Sensory Garden installation was carried out in a floor area of $40 \mathrm{~m}^{2}$ in flat topography location and soil classified as eutropherric red latosol with soil macro and micronutrient reserve.

The structure of the garden was built using recyclable materials. About 1,000 PET bottles were used for its structure, with sand added inside the bottles, to make the bottles rigid and resistant. The bottles were mounted side by side and tied with strings to stay together and give shape to planting beds. After structuring the beds with bottles, 5 $\mathrm{cm}$ of gravel was added to the bottom of planting beds for drainage. Afterward, fertile soil and plant substrate was added until reaching $20 \mathrm{~cm}$ height. Once the planting beds were ready, the plant species that make up the garden were transplanted in place. After transplantation, $20 \mathrm{QR}$ Code plates were added for plant identification, with botanical character information.

\section{Application of the first diagnostic questionnaire}

The activity was held with the ninth grade students of public high-school between the ages of 13 and 15 years old. The first contact took place in class, in which this research project was presented to the students explaining the research purpose and the students role in the study, making them aware of the no obligation to participate and, if someone was uncomfortable or embarrassed about the activity, the same could at any moment give up the participation. After presenting the research to students, the students were divided in two groups by a raffle, one group containing 12 students with access to the Sensory Garden and the other group containing 11 students without access to the Sensory Garden. After the division of the groups, the first diagnostic questionnaire was applied in the classroom, in order to assess whether the combination of the QR Code tool in a non-formal learning environment would be a valid idea, containing the following questions: i) What methods / instruments do you consider important for learning?; ii) Have you visited a garden before?; iii) Do you know the QR Code tool? If yes, have you used it?; iv) Do you believe that contact with the Sensory Garden and QR Code technology can help you in botanical learning?

\section{Application of the second diagnostic questionnaire}

After the first contact, students visited the non-formal learning environment. Students had contact with the plants present in the garden and made use of the senses through touch, smell, taste, sight, and hearing. In addition, they used the QR Code scanning technology to recognize plants and obtain more botanical information about species. After visiting the garden, we applied the second diagnostic questionnaire to the students present, in order to get the students opinion on the Sensory Garden experience and also to offer suggestions.

\section{Application of the third diagnostic questionnaire}

The last diagnostic questionnaire was applied in the classroom, with all 23 participating students, with more objective questions about Botany, to compare the two different groups and the evolution before and after the visit to the Sensory Garden. It is important to note that during the application of the last questionnaire there were no contacts between the students, in order not to compromise the research.

\section{Statistical analysis}

Completed the application of the diagnostic questionnaires, the obtained data were statistically rotated, in order to analyze the results generated.

The first questionnaire was applied in order to be the first 'contact' with students and their level of knowledge about 'non-formal learning environments' and QR Code technology. Initially, the 23 students ranked with numeric grades with a scale of 1 to 5 (1 unsatisfactory and 5 
satisfactory) the methods/instruments they considered most important for learning, having the following options: (i) Formal learning (inside classroom door); (ii) Nonformal learning (visits to gardens, museums, exhibitions and others); (iii) Use of newspapers, magazines and books; (iv) Use of technologies and applications; (v) Other. From these data, the means and the standard deviation were calculated to calculate the dispersion index of the sample in relation to the mean. In addition, the standard error was calculated to assess the reliability of the calculated mean of each option and the confidence interval with 5\% significance.

Still in the first questionnaires, student response frequencies were evaluated, obtaining the proportions of students who marked each alternative. After obtaining the proportions of each answer, the confidence interval with a $5 \%$ significance was evaluated.
The second diagnostic questionnaire was analyzed following the same pattern. For the third 'diagnostic questionnaire' the chi-square test was used, assessing the statistical difference between the group of students who visited the Sensory Garden compared to the group that had access only to the content addressed in the classroom.

\section{Results}

\section{First Diagnostic Questionnaire}

The options most accepted by students are in order of preference, with the most preferred first: the use of technologies and applications and formal education, followed by the non-formal learning environments, the use of newspapers, magazines and books and the option "others", in which students could suggest other methods of learning, such as through games and television programs (Table 1).

Table 1. Mean, standard deviation, standard error, and confidence interval values for questioning "What methods/ instruments do you consider important for learning? (Rate from 1 to 5 , being the 5 most important)"

\begin{tabular}{|c|c|c|c|c|c|}
\hline $\begin{array}{c}\text { Statistical parameters } \\
\text { / Answers }\end{array}$ & $\begin{array}{c}\text { Formal } \\
\text { Learning }\end{array}$ & $\begin{array}{c}\text { Non Formal } \\
\text { Learning }\end{array}$ & $\begin{array}{c}\text { Newspapers, } \\
\text { Magazines, and Books }\end{array}$ & $\begin{array}{c}\text { Technologies / } \\
\text { applications }\end{array}$ & Others \\
\hline Average & 4.5 & 4.0 & 3.5 & 5.0 & 1.0 \\
\hline Standard deviation & 1.20 & 1.53 & 1.82 & 1.42 & 1.18 \\
\hline Standard Error & 0.3 & 0.38 & 0.46 & 0.36 & 0.3 \\
\hline Confidence Interval & $3.91-5.09$ & $3.25-4.75$ & $2.61-4.39$ & $4.30-5.70$ & $0.42-1.58$ \\
\hline
\end{tabular}

The second question assessed whether students have ever visited gardens for didactic purposes, previously. Most students $(56.5 \%)$ never visited gardens, regardless of the purpose. The proportion of students who have already visited gardens for teaching purposes was $34.8 \%$, while $8.7 \%$ of students reported that they had garden visits, but without educational purpose, just for entertainment.
The questionnaire also assessed whether students had knowledge of QR Code technology and if they had the knowledge, if they have already made use of it. The last question addressed in the first diagnostic questionnaire, verified whether the student believes that the Sensory Garden in conjunction with QR Code technology can assist in botanical learning (Table 2).

Table 2. Statistical data obtained on the knowledge, use, and effectiveness of QR Code technology.

\begin{tabular}{|c|c|c|}
\hline \multicolumn{1}{|c|}{ Question } & \multicolumn{2}{|c|}{ Ratio and Confidence Interval } \\
\hline & Yes & Not \\
\hline Do you know the QR Code tool? & $62.5 \pm 5.93$ & $37.5 \pm 5.93$ \\
\hline If yes, have you made use of it? & $18.8 \pm 4.79$ & $81.3 \pm 4.79$ \\
\hline $\begin{array}{c}\text { Do you believe that contact with the Sensory Garden and QR Code technology can } \\
\text { help you in botanical learning? }\end{array}$ & $75 \pm 5.3$ & $25 \pm 5.3$ \\
\hline
\end{tabular}


As we can see the proportion of students unaware of the QR Code tool is high compared to students who know about it. Students who knew about the tool got to know from the applied pilot test of this study and some smartphone applications. In this last question, most students believe that the non-formal learning environment combined to $\mathrm{QR}$ Code technology can contribute in the botanical learning.

\section{Second Diagnostic Questionnaire}

The student's opinion about the Sensory Garden was evaluated. Only the team of students who visited the nonformal learning environments were interviewed. Initially, students were asked to rate the Sensory Garden with the following options: great, good, reasonable or bad. According to the data obtained, it was observed that among the students who visited the Sensory Garden, all responded positively to the activity, in which $57 \%$ of students answered "great", applying the confidence interval we obtained values between $43.29 \%$ and $71 \%$, and $43 \%$ of the students indicated the option "good", obtaining results between $29 \%$ and $56.71 \%$ in the confidence interval.

The second question aimed to evaluate students' level of interest in botany content after visiting the non-formal learning environment. Although the visit has a good rating among students, activity did not change the interest in botany for most visitors, being the "equal" alternative the most answered by the students $(71 \%)$, followed by "increased" (29\%) and the option decreased was not marked by any of the students. The third question assessed whether the use of the QR Code tool attracted students' attention, $71 \%$ of students were attracted by QR Code technology, $29 \%$ of students who were not attracted to the tool. The last question asks students if the Sensory Garden coupled with QR Code technology is a good tool for learning botanical content, all the visiting students from the garden said yes that such an environment assists in the learning.

\section{Third Diagnostic Questionnaire}

This questionnaire aimed to evaluate and compare the answers about the botanical content of the group of students who visited the Sensory Garden and the group that only had access to the content addressed in the classroom. We use the chi-square test (non-parametric test), which has as a principle to compare proportions and the results expressed in terms of odds ratio (chance of those who visited hit/chance of those who did not hit). Hits and errors of both groups were evaluated, to assess whether there was a significant difference between the two groups, a 5\% significance level was adopted, with a critical value of 3.84 .

The first question asks students about how plants feed. From the statistical test, the chance of those who visited the garden to answer the "photosynthesis" option and get it right was 6 times higher compared to those who didn't visit. This result is greater than the critical value of 3.84 , so this result has significance.

The second question was for students to identify the main characteristics of "angiosperms". None of the students who did not visit the Sensory Garden indicated the alternative "flowers and fruits", therefore all were wrong, and it was not possible to calculate the chance.
The third option asks students to mark the alternative that differentiates between "Monocotyledons" and "Eudicotyledons", the chance of students who visited the non-formal learning environment right by signaling the alternative "Parallel leaf rib and branched leaf rib" was 22.5 times the one who did not visit. Compared to the critical value of 3.84 , it makes the result significant.

In the fourth question, the essential elements for photosynthesis were questioned, such as carbon dioxide, water, and light. The chance of hit by those who visited the garden was 13.3 times that of those who did not visit, significant result, as it is higher than the critical value.

The fifth question questioned the students about how often plants breathe, "always" being the right alternative. The chance for students who visited the Sensory Garden to get it right was 4.17 times higher compared to those who didn't visit. Thus, this evaluation also proved to be a significant value compared to the critical value.

\section{Discussion}

From the data obtained we observed that students have difficulty absorbing the Botany content currently addressed in the classroom. According to Souza and Garcia (2019), the contents of biological areas are not attractive because they contain excessive nomenclatures, tables and the like to be memorized and many of the students do not relate the Vegetable Kingdom as 'living beings'. Thus, Melo et al. (2012) state the biggest obstacle with subjects on botany is decorative content and disconnected with its reality. Practical classes with topics in Botany are not common in elementary school, and the non-formal learning environment is an excellent resource to attract students' attention (Salatino and Buckeridge, 2016).

Our study also reported that the non-formal learning environment attracted students. The authors Vieira, Bianconi and Diaz (2005) affirm that the students better assimilate the contents approached in loco, and the environment and interaction are excellent triggers of attention and interest. Garden activities bring 'Man and the Environment' closer together, facilitating and motivating student learning. Migrating sporadically provides the opportunity for formal learning to be optimized in non-formal learning, which motivates student excitement and curiosity, from the investigative learning method and with significance (Lazzari et al., 2017). Some of the students who participated in the pilot test were already present in the final practical proposal, which may well justify the significant proportion of students who have visited didactic gardens. However, the high rate of students who have never visited a garden was already expected, since schools in the Public Education Network need to request permission from the Department of Education to promote student visits, and the need for transportation for all students (Queiroz et al., 2017).

We can observe that the use of new technologies attracts students by presenting novelties and efficiency, which leads students to seek to learn autonomously. Regrettably, many teachers are resistant to inserting technologies as a classroom study tool, because they have 'intellectual', not 'technological' formation, and technology is not properly 
used in the classroom because students 'push the envelope' using, often the tool for entertainment and leisure purposes in a formal learning environment (Prensky, 2010).

The use of QR Code technology is not popular and widespread in the classroom, by both teachers and students. The use of the tool was essential to captivate the attention of young people, as stated by Ribas et al. (2017), the use of smartphones and tablets is present in the reality of adolescents, it is necessary to configure them as a study tool, developing pedagogical activities that allow their use.

\section{Conclusions}

The proposal of inserting QR Code technology in a Sensory Garden (non-formal learning environment) as a botanical teaching tool was accepted among the students of the public High-school system and allowed students to interact with the plants observed in loco and among themselves, using the smartphone as a study tool.

The non-formal learning environment allowed students to come into contact with unknown plant species and even plants known only for culinary use. The presence of students among the plants grown in the garden sharpened their curiosity about different plant species and their functionalities. When comparing botanical knowledge among students, it was clear that participants who attended the Sensory Garden, previously, performed better than students who did not attend. Therefore, the non-formal learning environment 'Sensory Garden' with the use of QR Code technology was effective in learning and stimulating content from the area of botany, which reflected the understanding of this content.

\section{Author Contribution}

R.F.R.P. ${ }^{0000-0003-0711-8442:}$ project design, experiment setup, data

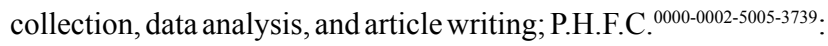
: project design, experiment setup, data collection and article writing; F.P. 0000-0002-0951-8274: experiment setup and orientation; D.B. ${ }^{0000-0001-9542-9413}$ : guidance at all stages of the work and participation in the review and writing of the project and article.

\section{Acknowledgments}

Authors are thankful to the Brazilian Council for Scientific and Technological Development (CNPq-PIBIC) [Grant number 143014/2018-8] by granting a scientific initiation scholarship to R. F. R. Prestes and the employees of Institutional Support Foundation for Scientific and Technological Development of the Federal University of São Carlos (FAI.UFSCar) for the collaboration in assembling the physical structure of the Sensory Garden.

\section{References}

CASCAIS, M.G.A.; TERÁN, A.F. Educação formal, informal e não formal na educação em ciências. Ciência em Tela, Rio de Janeiro, v.7, p.1-10, 2014.
LEÃO, J.F.M.C Identificação, seleção e caracterização de espécies vegetais destinadas à instalação de jardins sensoriais táteis para deficientes visuais, em Piracicaba(SP), Brasil. Revista Brasileira de Horticultura Ornamental, v.14, n.2, 2008.

FABENI, M.A. In: Mueller, C.C.; RAUSKI, E.F.; BASSANI, F.; MARINHO, H.R.B.; IAHN, L.F.; SANTOS, M.L.F.B., (Org.). Inovações Educativa e Ensino Virtual - Equipes capacitadas práticas compartilhadas. 3ed. Ponta Grossa: Estúdio Texto, 2015. pp.35-43.

LAZZARI, G.Z.; GONZATTI, F.; SCOPEL, J.M.; SCUR, L. Trilha ecológica: um recurso pedagógico no ensino da Botânica. Scientia Cum Industria, v.5, n.3, p.161-167, 2017.

MELO, E.A.; ABREU, F. F.; ANDRADE, A.B.; ARAUJO, M.I.O. A aprendizagem de botânica no ensino fundamental: Dificuldades e desafios. Scientia Plena, v.8, n.10, p.1-8, 2012.

NICHELE, A.G.; SCHLEMMER, E.; RAMOS, A.F. QR Codes na Educação em Química. Renote, v.13, n.2, p.1-9, 2015.

OLIVEIRA, B.S.; GUBAUA, C.A.; REIS, G.R.; CONTRERAS, H.S.H. O uso do aplicativo QR code como recurso pedagógico no processo de Ensino e aprendizagem. Ensaios Pedagógicos, v.7, n.2, p.12-21, 2017.

PRENSKY, M. O papel da tecnologia no ensino e na sala de aula. Conjectura, v.15, n.2, p.201-204, 2010.

QUEIROZ, R.M.; TEIXEIRA, H.B.; VELOSO, A.S.; TERÁN, A.F.; QUEIROZ, A.G. A caracterização dos espaços não formais de educação científica para o ensino de ciências. Revista Amazônica de Ensino de Ciências, v.4, n.7, p.12-23, 2017.

RIBAS, A.C.; SALATINO, A.; BUCKERIDGE, M. Mas de que te serve saber botânica? Estudos avançados, v.30, n.87, p.177-196, 2016.

SANTOS, V.P.; DIONÍSIO, M.M.C. Jardim sensorial Uma proposta de atividade pedagógica como ferramenta de educação ambiental. Revista UNIFEV: Ciência \& Tecnologia, v.1, n.1, p.87-96, 2016.

SOUZA, C.L.P.; GARCIA, R.N. Uma análise do conteúdo de Botânica sob o enfoque Ciência-Tecnologia-Sociedade (CTS) em livros didáticos de Biologia do Ensino Médio. Ciência \& Educação, v.25, n.1, p.111-130, 2019.

VIEIRA, V.; BIANCONI, M.L.; DIAS, M. Espaços nãoformais de ensino e o currículo de ciências. Ciência e Cultura, v.57, n.4, p.21-23, 2005. 